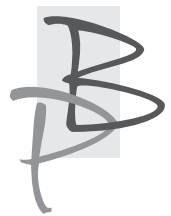

\title{
Economic Migration of Ukrainians to the EU: A View from Poland
}

Abstract: The present study aims to analyze several aspects of economic migration from Ukraine to Poland in the context of the last 10 years (2007-2017). It looks at how changes in migration policy in Poland and the EU impacted the dynamics of migration to Poland, which has been for a long time one of the most popular destinations for Ukrainians. In 2014, an increased number of Ukrainians migrating to Russia was observed, although no similar increase was recorded for EU countries (excluding Poland). In 2014, Polish consular services issued over 556,500 visas to Ukrainian citizens. Since 15 September 2012, Ukrainians no longer have to pay for national visas if they intend to stay in Poland for 3 months to 1 year. Since July 2009, the Agreement on Local Border Traffic between Poland and Ukraine has been in force. Based on this agreement, Ukrainian nationals residing in the border zone - the area extending $30 \mathrm{~km}$ from the border - do not need visas, only local border traffic permits entitling them to multiple crossings of the Polish border. The number of border crossings by Ukrainian citizens under the local

\footnotetext{
Natalia Chrobak is a PhD student in the Faculty of Philosophy at the Institute of Sociology at Jagiellonian University. She deals with research on long-term migration of Ukrainian citizens to Poland. She is interested in the impact of migration on the labor market. Some of her publications include: Article in the monograph, $W$ świecie protestu, Warsaw, Warszawskie Wydawnictwo Socjologiczne (2018); Book Syndrom Piotrusia Pana, Goneta (2014); Article Transformacja mediów w RPA, "Studenckie Zeszyty Naukowe Uniwersytetu Jagiellońskiego" (2014).
} 
border traffic agreement has been increasing each year (13 to $40 \%$ depending on year). It amounted to $10,734,959$ in 2015. My purpose is to present how migration law in Poland affects migratory waves.

Key words: Migration, Ukrainians, migrations to Poland, migrations from Ukraine, migration law.

Migrations are an inseparable element of every community's existence. Reasons to migrate are related to a diverse series of factors, including the individual's relationship with their environment, the interaction between individuals and politics, and various cultural and social conditions. This multiplicity of areas affects the motives for migration, causes of displacement, migration possibilities, and migration trajectories.

In analyzing migrations of Ukrainian residents, we see that there are several types of migration depending on external and internal factors ("push and pull factors") that motivate individuals to move ${ }^{1}$. According to Sergei Pirozhkova, among the inhabitants of Ukraine there are the following types of migration:

1. Economic migrations: migrations which are the result of a desire to improve their material situation;

2. Political migrations: migrations related to armed conflicts, change of state borders, etc;

3. Ecological migrations: migrations which are the result of the impact of the environment on health (this is especially about migrations that took place after the Chernobyl accident) ${ }^{2}$

The causes of migration change over time. The following article will present the changes that have occurred in the migrations from Ukraine to Poland.

1 G. Dorigo and W. Tobler, Push-pull migration law, "Annals of the Association of American Geographers", 73 (1): 1983, pp. 1-11

2 For: B. Termiński, Przesiedlenia inwestycyjne. Nowa kategoria migracji przymusowych, Warsaw: Łośgraf, 2012. 
Initially, the reasons for migration from Ukraine to Poland were economic reasons. This is noticeable before 2014, the Euromaidan. After 2014, migrations are caused not only by the desire to improve the economic situation, but also by the desire to permanently stay in Poland. The motive for migration is the desire to move away from the armed conflict in Crimea.

In 2017, at the time of writing this article, there was an increase in economic migration among Ukrainian citizens. These migrations are a challenge for both the host countries, i.e. the target for migrants, and for the sending country, i.e. the country of origin of the migrant. This intensification of population movements is increasingly evident in different areas of social life.

However, the reasons why Ukrainians want to migrate to Poland remain unchanged. The next part will present changes in the number of economic migrants, and in the last part, changes in the position of migrants on the labor market.

The article presents changes that have occurred in economic migration over the period of 10 years. The aim of the article is to present the changes and possible effects of economic migration, which changed from circular migration to settlement migration. So how are the migrations from Ukraine to Poland changing and what long-term effects may they cause?

\section{Why do migrants migrate? Causes of the migration of Ukrainians}

In Poland, there has been a significant increase in the number of migrants from the former Soviet Union. The most numerous migrant group is comprised of people who hold Ukrainian citizenship. The number of people from Ukraine wishing to settle in Poland has been gradually increasing. In 2008 there were 12,000 Ukrainian citizens who received a residence card to settle in Poland, while in 2013, the number increased to almost $18,000^{3}$.

In the case of the migration of Ukrainians, economic migration is quite common. This type of migration is characterized by the movement of a professionally active population that wants to improve their own and/or their family's financial situation by migrating and taking up employment in the target country ${ }^{4}$.

3 Z. Bunarska, Studia BAS Biura Analiz Sejmowych kancelarii sejmu, No. 4 (40) 2014, p. 157.

4 M. Stoczek, Wspótczesne migracje zarobkowe. Regionalne studia porównawcze, [in] J. Zamojski (ed.), Migracje i społeczeństwo, Warsaw: "PAN”, 1997, p. 13. 
The migrations undertaken by Ukrainians are also very often "shuttle migrations"5. This means that migrants from Ukraine come to Poland for a period of 3 to 6 months, return to Ukraine where they spend several months, and then come back to Poland. This is enabled by migration networks (which are still being developed by incoming migrants), ease of obtaining a visa and taking up legal work, and a special bond connecting the sending and receiving country. In the case of Ukraine, these include geographic proximity, history of the countries, and similar culture ${ }^{6}$.

There are several reasons for Ukrainian citizens to come to Poland. The most important include:

1. Unemployment rate and delayed payment of wages: According to data of the State Statistics Service of Ukraine, in 2015 the unemployment rate in Ukraine was $9.1 \%{ }^{7}$. This level of unemployment seems comparable to the situation in Poland, where in December 2015 the unemployment rate was almost $10 \%$ according to data form the Central Statistical Office ${ }^{8}$. It should be noted, however, that the actual unemployment rate could be much higher. This is related to, among other factors, late payment of salary. According to the Ukrainian National Statistics Service, 52\% of Ukrainian citizens did not receive their remuneration in 2015. At the moment, occupation by rebels in Ukraine is also contributing to the increase in the unemployment rate. The highest level of unemployment in the first quarter of 2015 was recorded in the Luhansk region (15.3\%), Donetsk (14.4\%), Poltava (13.9\%), Tarnopol (12.4\%) and the Black Sea and Kirovograd oblasts (11.8\%), and the lowest - in Kiev (6.4\%), Odessa Oblast (6.6\%) and Kharkiv (7.4\%) .

5 R. P. W. Jennissen, Macro-economic Determinants of International Migration in Europe, Sittard: Rozenberg Publishers, 2004, pp. 3-9.

6 H. Zlotnik, Empirical identification of international migration systems, [in] M. Kritz, L. Lean, H. Zlotnik (eds.), International Migration Systems: Global Approach, Oxford: Clarendon Press, 1992, pp. 19-40.

7 УКРАЇНА - 2015, Державна служба статистики України, СТАТИСТИЧНИЙ ЗБІРНИК, Kiev, 2016, p. 10.

$8 \quad$ Stopa bezrobocia $w$ latach 1990-2016, http://stat.gov.pl/obszary-tematyczne/rynek-pracy/ bezrobocie-rejestrowane/stopa-bezrobocia-w-latach-1990-2016,4,1.html, access: 19.02.2016.

9 N. Szymborska, M. Gawin, Przegląd aktualności gospodarczych na Ukrainie, 22-28 czerwca 2015 r., No. 25/2015 (364), Wydział Promocji Handlu i Inwestycji Ambasada RP w Kijowie, p. 11. 
2. Geographic, spherical, linguistic and social proximity: Both countries share a common history, as well as socio-economic and political-economic experiences. Both Poland and Ukraine remained under the control of the Soviet Union during the isolation of the Eastern Bloc and the centrally controlled economy. In addition, there were parts of Ukraine that, until the Second World War, were part of Polish territory. Geographic proximity and a common history make it relatively easy for Ukrainians to complete the formalities related to entry/arrival ${ }^{10}$.

3. Simple arrival processes of legalization: Before Poland found itself in the Schengen area, Ukrainian citizens could cross the border without passport-visa formalities. After Poland joined the European Union and then the Schengen area, Ukrainian citizens were required to have a "short-term Schengen uniform visa, long-term Polish national visa (D), residence permit in Poland, or a residence permit or national visa issued by another Schengen state" 11 . This ease of entry into the territory of Poland compared to the countries of Western Europe is becoming one of the reasons why migrants from Ukraine choose Poland as the country of destination.

4. The armed conflict in Ukraine: With the armed conflict of the Donbas region in eastern Ukraine, comprising a population of around 5 million people in the Donetsk and Lugansk oblasts, the number of migrants from Ukraine to Poland significantly changed. Previous Ukrainian migrations were mainly economic in nature and a way of addressing poverty and long-term unemployment. During the conflict in the Crimea, the mobility of people living in the eastern part of Ukraine increased significantly. According to data from 2015, the status of Internally Displaced Persons rose to $1,369,844$ Ukrainian citizens living in the Crimea ${ }^{12}$.

In the case of external migration of Ukrainians to the countries of the European Union, exact data are not known. According to the information published

10 Warunki wjazdu do Polski dla obywateli państw trzecich objętych obowiazkiem wizowym, http://www.msz.gov.pl/pl/informacje_konsularne/przyjazd_do_polski/zasady/, access: 19.02.2016.

11 Мінсоцполітики - Ministerstwo Polityki Społecznej Ukrainy z roku 2015.

12 Odpowiedź na interpelację nr 34620 w sprawie przyjęcia imigrantów do Polski, http:// www.sejm.gov.pl/sejm7.nsf/InterpelacjaTresc.xsp?key=0F1AF095, access: 18.03.2017. 
on the Sejm's website (Polish Senate), from January to August 2015, 597,511 visas were issued to Ukrainian citizens (including 283,215 Schengen visas and 314,296 domestic visas). Almost 25,000 visas for temporary stay in the period from January to October were given, of which $59 \%$ of permits concerned residence permits related to paid work. On the other hand, 467 citizens of Ukraine received a long-term resident permit in the European Union ${ }^{13}$. The majority of migrants from areas subject to armed conflict decided to legalize their stay in Poland, enabling them to work if they chose an application for international protection for the first 6 months of their stay, and they would not be able to work. Analyzing the reasons for the migration of Ukrainian citizens, it can be noted that these are mainly people who want to escape from the area directly affected by the armed conflict, where they cannot be under the protection of the Ukrainian government, and those who want to avoid compulsory conscription. In previous years, specifically from 2006 to 2013, the main reason for the migration of Ukrainian citizens to Poland was the desire to improve their economic situation.

In addition, one should also distinguish individual motivations that occur among migrants from Ukraine, the so-called "push and pull factors".

Table 1. Types of motivation - push and pull factors

\begin{tabular}{|l|l|l|}
\hline Type of motifs & "Push out factors" & "Attractive factors" \\
\hline $\begin{array}{l}\text { Economic and } \\
\text { demographic }\end{array}$ & $\begin{array}{l}\text { poverty, unemployment, low wages, } \\
\text { high natural increase, lack of basic } \\
\text { medical care, deficiencies in the } \\
\text { education system }\end{array}$ & $\begin{array}{l}\text { higher earnings prospects, } \\
\text { prospects improving the standard } \\
\text { of living, personal or professional } \\
\text { development }\end{array}$ \\
\hline Political & $\begin{array}{l}\text { conflicts, danger, violence, } \\
\text { corruption, human rights violations }\end{array}$ & $\begin{array}{l}\text { sense of security, } \\
\text { freedom political }\end{array}$ \\
\hline $\begin{array}{l}\text { Social and } \\
\text { cultural }\end{array}$ & $\begin{array}{l}\text { discrimination based on reasons } \\
\text { ethnic and / or religious }\end{array}$ & $\begin{array}{l}\text { migration to the country of } \\
\text { ancestors, no discrimination } \\
\text { phenomenon }\end{array}$ \\
\hline
\end{tabular}

Source: A. Mansor, B. Quillin, (Eds.), Migration and Remittances. Eastern Europe and the former Soviet Union, "The World Bank", Washington, 2006, p. 78.

13 Cudzoziemcy pracujacy w Polsce - statystyki, https://www.mpips.gov.pl/analizy-i-raporty/ cudzoziemcy-pracujacy-w-polsce-statystyki/, access: 18.03.2017. 
In the case of the analyses from 2005 to 2015 , the main factors are:

1. Low wages, untimely payment of wages: The occurrence of this factor is especially noticeable among the residents of the western part of Ukraine. However, after 2014, i.e. after Euromaidan, the inhabitants of the eastern part of the country began to migrate because of this factor.

2. Political: After 2014 migration is related to the impact of both push and pull factors. The reason for this is the fact that with Euromaidan, war, and the earlier Crimean Orange Revolution in Ukraine, there are challenges in political stability, labor market and territorial issues. As a result, according to the Office for Foreigners, the number of applications for permission to reside for a fixed period or temporary stay and for a permit to settle or permanent residence increases. The number of applications for a settlement permit or permanent residence for 2007 was 2059, while in 2015 it increased to 8,872 .

There are many reasons for the migration of Ukrainian citizens. Many of them depend on external factors, such as easier legalization processes, as well as internal factors related to, for example, insecurity or untimely payment of salary. In the analyzed period, i.e. from 2005 to 2015, the causes of migration changed, as indicated by, among others, motivations of Ukrainian citizens who want to leave the country.

\section{Economic migrations of Ukrainian citizens}

The migration of Ukrainian citizens to Poland is mainly of an economic nature. This means that the goal of migrants is to improve their financial situation. Both short-term and long-term migrants move to work.

Before the annexation of Crimea to Russia, the Ukrainians' migrations showed a slow tendency of decreasing. From 2005 until 2008, 1.5 million Ukrainians aged between 17 and 70 worked or looked for work abroad, while from 2010 to 2012 this number dropped to 1.2 million people ${ }^{14}$. This declining number of migrants was related to the global economic crisis and the change of

$14 \mathrm{O}$. Betliy, Migration between the EU, V4 and Eastern Europe: The present situation and the possible future. The perspective of Ukraine, [in] M. Jaroszewicz, M. Lesińska (eds.), Forecasting Migration Between the EU, V4 and Eastern Europe Impact of Visa Abolition, Warsaw: Ośrodek Studiów Wschodnich im. Marka Karpia, 2014, p. 161. 
migration strategies of Ukrainian citizens. More and more often they chose temporary and circular migration (pendulum). Such migration allowed Ukrainians, among others, to maintain social networks in their country of origin. The fact that both Poland and Russia significantly eased their migration policy influenced the choice of this kind of migration, which allowed Ukrainians to cross borders more easily and work legally in the host country ${ }^{15}$. A change in the number of migrants and their type occurred after 2014. The influx of Ukrainians to Poland is related to the Euromaidan of 2013 and the armed conflict in Crimea in 2014. According to data from the Ministry of Labor, in 2015 it issued almost 30,000 work permits for citizens of Ukraine. The largest number of permits issued concerned residence in Poland for a period of 3 months to a year ${ }^{16}$.

Analyzing the waves of economic migrants, there is a positive correlation between Ukraine's GDP and the number of applications filed by citizens of Ukraine for a residence permit for a fixed period or temporary stay, and for a permit to settle or permanent residence in Poland.

15 M. Jaroszewicz, Polska bardziejatrakcyjna dla ukraińskich imigrantów zarobkowych, http:// www.osw.waw.pl/pl/publikacje/analizy/2013-06-12/polska-bardziej-atrakcyjna-dla-ukrainskichimigrantow-zarobkowych, date of publication: 12.06.2013, access: 18.03.2017.

16 Information on the employment of foreigners in Poland, the Ministry of Home, Labor and Social Policy Dept. of the Labor Market, https://www.mpips.gov.pl/gfx/mpips/userfiles/_public/1 NOWA\%20STRONA/Analizy\%20i\%20raporty/cudzoziemncy\%20pracujacy\%20w\%20polsce/ Zatrudnienie\%20cudzoziemcow\%20grudzien\%202015\%20r.popr.pdf, access: 18.03.2017. 
Chart 1. GDP global value (according to the exchange rate, USD billion)

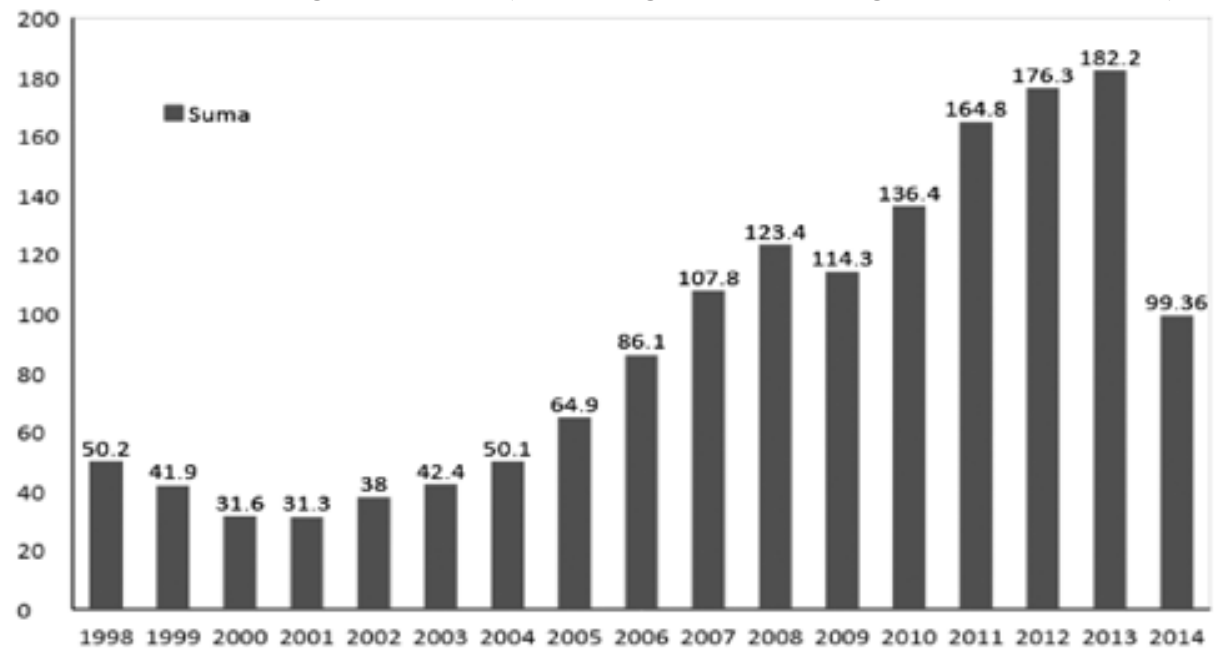

Source: Based on World Bank data, http://databank.worldbank.org/data/reports.aspx? source $=2 \&$ type $=$ metadata $\&$ series $=$ NY.GDP.MKTP.CD $\#$, access:18.03.2017 .

Table 2. The number of people who in the years 2007-2015 submitted an application for a residence permit for a fixed period or a temporary stay

\begin{tabular}{|c|c|c|c|c|c|c|c|c|c|}
\hline Year & 2007 & 2008 & 2009 & 2010 & 2011 & 2012 & 2013 & 2014 & 2015 \\
\hline number & 8558 & 9054 & 9609 & 9844 & 9114 & 11743 & 11111 & 23390 & 58740 \\
\hline
\end{tabular}

Source: Statistical bulletin, http://udsc.gov.pl/statystyki/raporty-okresowe/, access: 1.11.2016.

Table 3. Number of persons who in the years 2007-2015 filed an application for a permit to settle or permanent residence

\begin{tabular}{|c|c|c|c|c|c|c|c|c|c|}
\hline Year & 2007 & 2008 & 2009 & 2010 & 2011 & 2012 & 2013 & 2014 & 2015 \\
\hline number & 2059 & 1725 & 1534 & 1895 & 2008 & 2248 & 1980 & 4645 & 8872 \\
\hline
\end{tabular}

Source: Statistical bulletin, http://udsc.gov.pl/statystyki/raporty-okresowe/, access: 01.11.2016. 
On the basis of the above data, three migration waves of economic migrants were distinguished:

1. The economic crisis in Ukraine from 1998 to 2002 (the crisis in Russia was the reason for the collapse of the economy of Ukraine): In this period, the economy of Ukraine depended on the Russian economy, which caused a sharp drop in production exports in Ukraine, which translated into an increase in unemployment and inflation. Ukrainian citizens were having problems with obtaining a visa. There were also job placement issues, while the Polish labor market had a low demand for workers from Ukraine. It should also be mentioned that during this period, the Polish economy was experiencing a crisis, revealing hidden unemployment and privatization of state-owned companies.

2. The global economic crisis in 2008: The increase in the number of migrants in Poland was also related to the liberalization of regulations, mainly for people migrating to Poland from the former Soviet Union in 2006.

3. Euromaidan and the Crimean Crisis from 2014 to the present: There has been further liberalization of regulations regarding the flow of migrants, taking up work on the territory of Poland, and the possibility of recognizing diplomas acquired in the countries of the former Soviet Union.

\section{Migrant, foreigner, employee legal situation of Ukrainian citizens on the territory of Poland}

According to information contained in the European Social Charter, in Article 19 an employee arriving in another country is "a citizen of one country, which another country allowed to stay on its territory, in order to take up hired work there"17. The Council of Europe also draws attention to the process of integration and assimilation of migrant workers. Integration is understood as involving migrants and increasing their participation in the social institutions of the host country. Assimilation, on the other hand, is understood as the acceptance by migrants of worldviews and values professed by the host country, while rejecting the values and worldviews prevailing in the sending country. In

17 European Convention on the Status of Rights of a Migrant Worker No. 093 of November 24, 1977. 
the case of migrants from Ukraine, integration and assimilation are relatively simple, as has been mentioned above: both countries have a similar culture and have experienced similar economic and ideological changes. In addition, the migration networks that Ukraine's migrants enjoy are relatively permanent, which is part of the reason why it is easy for them to assimilate.

From Article 11 of Convention No. 97 from 1949 of the International Labor Organization (ILO), a migrant worker is "a person who emigrates from one country to another to take up employment other than on his own account" and "any person admitted in accordance with the regulations to employment in the nature of a migrant worker"18. Therefore, there is no proper definition of an employee who has received a settlement permit and has started work in the host country. In addition, in Polish legislation at the time of writing this paper, due to the low participation of migrants in the labor market, there have been no clearly defined rules about who they are and what are the rights of a migrant wishing to work in Poland.

People coming to Poland for both short and long periods of time are referred to as "foreigners", and the basic legal act defining and regulating their legal stay on the territory of Poland is the Act on foreigners of December 12, 2013 (Journal of Laws of 2013., item 1650). On the other hand, the act in force on the territory of the European Union allowing entry into the EU is the Act of 14 July 2006 (Journal of Laws No. 144, item 1043, as amended).

The basic legal acts regulating the possibility of foreigners taking up work are:

1. The Act on Promotion of Employment and Labor Market Institutions of April 20, 2004 (Journal of Laws of 2013, item 674, as amended);

2. Act on foreigners of 12 December 20013 (Journal of Laws of 2013, item 1650);

3. Act on the legalization of the stay of some foreigners on the territory of the Republic of Poland and on the amendment to the act on granting protection to foreigners within the territory of the Republic of Poland, and the Act on foreigners of 28 July 2011 (Journal of Laws No. 191, item 1133). 
Legislation on the employment of foreigners (migrants) in force in Poland so far focuses on employing highly qualified employees (financial services, banking, corporate employees, senior managers) and employing people with low qualifications (employees in industries such as agriculture, household maintenance, construction).

However, the number of people coming from the countries of the former Soviet Union is now gradually increasing, with people who want to settle in Poland and take up a job requiring higher qualifications in Poland. To help them take up legal employment, it is easier for them to be employed in companies in Poland based on the provisions of the Ordinance of the Minister of Labor and Social Policy of 20 July 2011 in cases in which it is permissible to entrust work to a foreigner on the territory of the Republic of Poland without the need to obtain a work permit (Journal of Laws No. 155, item 919). These regulations make it easier for migrants coming from Belarus, Russia or Ukraine to work in Poland. These persons can work legally in Poland for 6 months, then during the next 12 months it is necessary that the employer registered in the local labor office submit a statement on the employment of a foreigner.

A notable increase in the number of migrants also resulted in the adoption of a new law by the Sejm (Polish Senate, which entered into force on 1 May 2015. This act is the adaptation of Polish migration law to EU arrangements. Under this Act, migrants (foreigners - definition from Polish legislation) may stay legally on Polish territory for up to 3 years (previously it was a maximum of 2 years). In addition, a foreigner may apply for a period of time enabling them to extend their stay. Previously, the relevant application had to be submitted within 45 days before the end of the residence permit or visa validity.

The procedures for employing foreigners were also made simpler. Before the entry into force of the above law, the employer was forced to apply for a work permit for an employee who did not have Polish citizenship, and only after obtaining consent could the migrant apply for a permanent residence permit. At the time of writing, the municipal office does not check where the worker lives or by what means. It is sufficient for them to show that they have a place to live in Poland. This law is to a large extent to help migrants take up legal employment in Poland. Polish law is not yet 
fully adapted to arriving migrants, including laws regarding the protection of their rights or defining their rights and obligations in Poland. The laws protecting foreigners at the moment refer directly to refugees and asylum seekers. They are:

1. The Constitution of the Republic of Poland of 2 April 1997 (Journal of Laws No. 78, item 483, as amended);

2. Act on granting protection to aliens within the territory of the Polish Republic dated 13 June 2003 (i.e. Dz. U. of 2012., Pos. 680);

3. Social Assistance Act of 12 March 2004 (i.e. Dz. U. of 2013., Pos. 182);

4. The Law on supporting the family and foster care system, of 9 June 2011 (i.e. Dz. U. of 2013., Pos. 135).

Thus, it can be acknowledged that the current changes in Polish legislation concerning migrants, their stay and work on the territory of Poland, are aimed at limiting the occurrence of illegal migration and the employment of migrants in the "gray zone".

\section{Conclusions}

At the time of writing this paper, most Ukrainians on the Polish labor market were people coming to Poland for a period of 3 to 6 months. According to research carried out by the National Bank of Poland in the Warsaw agglomeration, 710 people in the first half of 2015 show that Ukrainians on average were earning $34 \%$ less than Poles in these positions. On the other hand, the analysis of weekly working time is on average 60 hours (150\% of the time), and the hourly rate is 10 PLN net ${ }^{19}$. People from Ukraine working in Poland have often agreed to do the same work as Polish citizens for longer hours and for lower wages. However, it should be noted that migrants from Ukraine present a type of short-term, shuttle and economic migration. This means that their work in Poland has a temporal dimension and funds obtained in Poland are largely spent in Ukraine. Therefore, they may not affect the Polish labor market to a significant extent. Therefore, it can be argued that employees from Ukraine employed in Poland do not significantly affect:

19 Kwartalny raport o rynku pracy w I kw. 2016 r., http://www.nbp.pl/publikacje/rynek_pracy/ rynek_pracy_2016_1kw.pdf, access: 18.03.2017. 
1. The amount of salary in Poland: Due to the fact that migrants from Ukraine usually stay in Poland from 3 to 6 months, they do not have a long-term outflow of remuneration for Polish citizens working in the same positions. In addition, the temporary migration dimension makes it easier for a Polish employer to train a Polish employee and employ them for longer rather than regularly changing Ukrainian employees. In addition, Polish law provides employees with a minimum amount of remuneration that they should receive for their work. Ukrainian citizens often work in jobs that Poles do not want to take on, which is why they cannot be fully replaced. A negative aspect of the impact of migrants on wages is observed in the area of their wages. This means that with their higher inflow, migrants' salaries are falling. A positive effect, which is noticeable in the case of migrants from Ukraine coming to Poland, is that they increase the efficiency of the positions they work in, e.g. they work a greater number of hours a week.

2. The unemployment rate: Due to the temporary dimension of migration and the lack of impact of their presence on the wages of local workers, the unemployment rate is largely unaffected. The employment of foreigners is connected not with the replacement of Polish employees with migrants, but with the demand for work. This means that employees from Ukraine are most often employed in those sectors in which Poles do not want to work.

However, this does not change the fact that in the last 10 years migrations of Ukrainians to Poland have been subject to change. Many Ukrainian citizens migrated to Poland mainly for commercial purposes. According to data from 2012 , as many as $70 \%$ of migrants came from western Ukraine, $10.8 \%$ from the central part, and $1 \%$ from the eastern part ${ }^{20}$. However, with the armed conflict in the Crimea, economic crises that affect Ukraine, compulsory conscription to the army, and a facilitated possibility of migration, the goals and time of migration of Ukrainian citizens are changing. The number of applications requesting temporary or permanent residence has increased. In 2013, 20,400

20 International Labor Organization, Report on the Methodology, Organization and Results of a Modular Sample Survey on Labor Migration in Ukraine, http://www.ilo.org/wcmsp5/groups/ public/---europe/---ro-geneva/---sro-budapest/documents/publication/wcms_244693.pdf, access: 18.03.2017, pp. 37-40. 
Ukrainians were given work permits, and the applications of 217,600 Ukrainian citizens were registered ${ }^{21}$.

Analyzing the above data, it can be concluded that the inflow of Ukrainians to Poland can become both a positive and a negative phenomenon for the Polish economy. A positive sign of the growing number of migrants on the Polish labor market is that they undertake work that is not desired by Polish citizens in sectors such as construction or agriculture. As a result, they enable the development of enterprises related to these sectors. On the other hand, the negative aspect of the influx of migrants from Ukraine may turn out to be partly unregulated by the Polish law of flow and non-compliance with the law, among others, such as the use of social welfare, health care, etc. by foreigners. In addition, highly qualified employees who become competitive for Polish citizens are beginning to arrive in Poland. The influx of migrants to Poland from Ukraine affects some labor market areas. In 2015, an increase in workers from Ukraine wanting to work in medicine-related areas was noted. In 2015, 123 work permits were issued, for example for doctors, nurses or midwives ${ }^{22}$. In 2009, according to the Ministry of Labor and Social Policy, there were only 64 such persons.

To sum up, the inflow of migrants from Ukraine to Poland is becoming more and more noticeable. An increasing number of Ukrainian citizens want to settle in Poland, as a result of which they will start to influence the Polish labor market. However, this situation may change depending on external and internal factors that relate to the movement of people and their possibilities.

21 J. Konieczna-Sałamatin, Imigracja do Polski w świetle danych urzędowych, http:// www.i-see.org.pl/strona/uploads/ngrey/Documents/Analiza_danych_urzedowych_JKS.pdf, access: 18.03.2017.

22 Na podstawie raportów Cudzoziemcy pracujący w Polsce - statystyki, https://www.mpips. gov.pl/analizy-i-raporty/cudzoziemcy-pracujacy-w-polsce-statystyki/, access: 18.03.2017. 


\section{References}

Act 11 of Convention No. 97 of 1949 of the International Labor Organization. Betliy, O. (2014). Migration between the EU, V4 and Eastern Europe: The present situation and the possible future. The perspective of Ukraine. In M. Jaroszewicz, \& M. Lesińska M. (Eds.), Forecasting Migration Between the EU, V4 and Eastern Europe Impact of Visa Abolition (p. 161). Warsaw: Ośrodek Studiów Wschodnich im. Marka Karpia.

Bunarska, Z. (2014). Studia BAS Biura Analiz Sejmowych kancelarii sejmu Nr 4(40), p. 157.

Cudzoziemcy pracujący w Polsce - statystyki. https://www.mpips.gov.pl/analizy-iraporty/cudzoziemcy-pracujacy-w-polsce-statystyki/ (accessed 18 March 2017). Socialno-jekonomicznie stanowiszcze Ukraïniza 2015 rik, Powidomlennia Dierżawnoï służbi statistiki Ukraï. http://www.ukrstat.gov.ua/druk/soc_ek/2015/ publ_12_2015_u.html (accessed 19 February 2016).

Dorigo, G., \& Tobler, W. (1983). Push-pull migration laws. Annals of the Association of American Geographers, 73(1), 1-11.

European Convention on the Status of Rights of a Migrant Worker No. 093 of November 24, 1977 (2012). In B. Termiński (Ed.), Przesiedlenia inwestycyjne. Nowa kategoria migracji przymusowych. Łośgraf.

International Labour Organization, Report on the Methodology, Organization and Results of a Modular Sample Survey on Labour Migration in Ukraine (pp. 37-40). http://www.ilo.org/wcmsp5/groups/public/---europe/---ro-geneva/---sro-budapest/ documents/publication/wcms_244693.pdf (accessed 18 March 2017).

Jaroszewicz, M. (2013). Polska bardziej atrakcyjna dla ukraińskich imigrantów zarobkowych. http://www.osw.waw.pl/pl/publikacje/analizy/2013-06-12/polska-bardziej-atrakcyjna-dla-ukrainskich-imigrantow-zarobkowych (accessed 18 March 2017).

Jennissen, R. P. W. (2004). Macro-economic Determinants of International Migration in Europe. Sittard: Rozenberg Publishers.

Konieczna-Sałamatin J., Imigracja do Polski w świetle danych urzędowych. http:// www.i-

see.org.pl/strona/uploads/ngrey/Documents/Analiza_danych_urzedowych_KS.pdf (accessed 18 March 2017).

Kwartalny raport o rynku pracy w I kw. 2016 r. 
http://www.nbp.pl/publikacje/rynek_pracy/rynek_pracy_2016_1kw.pdf （accessed 18 March 2017).

Minsocpołitiki - Ministerstwo Polityki Społecznej Ukrainy z roku 2015.

Na podstawie raportów Cudzoziemcy pracujący w Polsce - statystyki.

https://www.mpips.gov.pl/analizy-i-raporty/cudzoziemcy-pracujacy-w-polscestatystyki/ (accessed 18 March 2017).

Odpowiedź na interpelację nr 34620 w sprawie przyjęcia imigrantów do Polski.

http://www.sejm.gov.pl/sejm7.nsf/InterpelacjaTresc.xsp?key=0F1AF095 (accessed 18 March 2017).

Stoczek, M. (1997). Współczesne migracje zarobkowe. Regionalne studia porównawcze. In J. Zamojski (Ed.), Migracje i społeczeństwo (p. 13). Warsaw: PAN.

Stopa bezrobocia w latach 1990-2016. http://stat.gov.pl/obszary-tematyczne/rynek-pracy/bezrobocie-rejestrowane/stopa-bezrobocia-w-latach-1990-2016,4,1. html (accessed 19 February 2016).

Szymborska, N., \& Gawin, M. (2015). Przegląd aktualności gospodarczych na Ukrainie, 22 - 28 czerwca 2015 r. Nr 25/2015 (364) (p. 11). Wydział Promocji Handlu i Inwestycji Ambasada RP w Kijowie.

Warunki wjazdu do Polski dla obywateli państw trzecich objętych obowiązkiem wizowym.

http://www.msz.gov.pl/pl/informacje_konsularne/przyjazd_do_polski/zasady/ (accessed 19 February 2016).

UKRAÏNA - 2015, Dierżawna służba Statistikiukraïni, STATISTICZNIJ ZBIRNIK (2016). Kijów, p. 10.

Zlotnik, H. (1992). Empirical identification of international migration systems. In M. Kritz, L. Lean, \& H. Zlotnik (Eds.), International migration systems: Global Approach (pp. 19-40), Oxford: Clarendon Press. 